\title{
Juveniles of the piscivorous dourado Salminus brasiliensis mimic the piraputanga Brycon hilarii as an alternative predation tactic
}

\author{
Eduardo Bessa ${ }^{1,2}$, Lucélia Nobre Carvalho ${ }^{3}$, José Sabino ${ }^{4}$ and Paola Tomazzelli ${ }^{1}$
}

In the district of Bom Jardim, in Nobres, Mato Grosso State, Brazil, there are clear water streams originating on karstic terrain. The dourado, Salminus brasiliensis, is an apex stalking predator in these streams. In clear waters, where visually oriented prey may perceive predator in advance, surprise is needed for successful attacks. These streams are cohabited by other Characiformes, like the frugivorous piraputanga Brycon hilarii, which lives in schools and exhibits body colour and shape similar to the dourados. Here we describe an alternative predatory tactic for juvenile dourado occurring in headwater streams of the Paraguay River basin, in which they act as an aggressive mimic of the piraputanga. Based on $43 \mathrm{~h}$ of observations in Bom Jardim, and on additional $11 \mathrm{~h}$ in the Bodoquena Plateau Rivers of Mato Grosso do Sul State, we quantified the number of rushes by dourados when they were among piraputangas or foraging alone, and observed the proportion of piraputangas per dourado in multispecific schools. Dourados of up to $30 \mathrm{~cm}$ total length (TL) stayed among the piraputangas of similar size hiding within the school and going to the periphery of the school before rushing against prey. The dourados exhibited colours similar to the piraputangas. They not only stayed longer among piraputangas ( $78 \%$ of the observation time), but also rushed against prey more often than when foraging alone (53 rushes/h against 14 rushes/h, respectively).

No distrito de Bom Jardim, Nobres, Mato Grosso, Brasil, existem rios de águas claras que se originam sobre terreno cárstico. O dourado, Salminus brasiliensis, é um predador perseguidor de topo de cadeia nestes rios. Em águas, onde presas visualmente orientadas são capazes de perceber antecipadamente o predador, o fator surpresa é necessário para ataques bem sucedidos. Estes córregos são coabitados por outros Characiformes, como a frugívora piraputanga, Brycon hilarii, a qual vive em cardumes e exibe coloração do corpo e forma similares aos dourados. Aqui descrevemos a ocorrência de uma tática predatória alternativa para dourados juvenis, na qual eles agem como mímicos agressivos da piraputanga. Baseados em $43 \mathrm{~h}$ de observação em Bom Jardim e $11 \mathrm{~h}$ adicionais em riachos da Bodoquena, Mato Grosso do Sul, nós quantificamos o número de arremetidas do dourado quando estava entre as piraputangas ou forrageando sozinhos e observamos a proporção de piraputangas por dourado em cardumes multiespecíficos. Dourados de até $30 \mathrm{~cm}$ de comprimento total permaneceram entre as piraputangas de tamanho similar, escondendo-se em meio ao cardume e indo à periferia deste antes de arremeter contra suas presas. Os dourados exibiam cores similares às da piraputanga. Eles não só permaneceram mais tempo entre as piraputangas $(78 \%$ do tempo de observação), mas também arremeteram mais frequentemente contra as presas do que enquanto forrageavam sozinhos (53 arremetidas/h contra 14 arremetidas/h, respectivamente).

Key words: Characid, Feeding behavior, Mimicry, Underwater observations.

\footnotetext{
${ }^{1}$ LECR - Laboratório de Ecologia Comportamental da Reprodução. Universidade do Estado de Mato Grosso, Câmpus de Tangará da Serra. Rodovia MT 358, Km 7, Jardim Aeroporto, 78300-000 Tangará da Serra, MT, Brazil. prof.bessa@yahoo.com.br

${ }^{2}$ UNESP - Depto. de Zoologia e Botânica, Instituto de Biologia, Letras e Ciências Exatas. Programa de Pós-Graduação em Biologia Animal. Rua Cristovão Colombo, 2265, Jardim Nazareth, 15054-000 São José do Rio Preto, SP, Brazil.

${ }^{3}$ NEBAM - Núcleo de Estudos de Biodiversidade da Amazônia Mato-grossense. ICNHS - Instituto de Ciências Naturais, Humanas e Sociais. Universidade Federal do Mato Grosso, Câmpus Universitário de Sinop. Av. Alexandre Ferronato, 1200, Setor Industrial, 78557-267 Sinop, MT, Brazil. carvalholn@yahoo.com.br

${ }^{4}$ Universidade Anhanguera - Uniderp, Projeto Peixes de Bonito. 79037-280 Campo Grande, MS, Brazil. jose.sabino@pq.cnpq.br
} 
Aggressive mimicry is an opportunistic interaction in which predators join other similar species for surprising its prey (Wickler, 1968). The model taxa are generally planktivores, micro-carnivores or herbivores, partially or completely harmless to the mimic's preys (see Auster, 2008 for an exception). In marine fishes this interaction is well documented with records for eight families (e.g., Eibl-Eibesfeldt, 1955; Randall \& Randall, 1960; Hobson, 1974; Sazima et al., 2005; see revision in Randall, 2005), although in freshwater few cases are known until now (Sazima, 2002). In the Neotropics, interactions between piranha species and small characids compose one of the few records of aggressive mimics and their models (Sazima, 1977; Nico \& Taphorn, 1988; Sazima \& Machado, 1990), added by a noteworthy example between the juvenile of Erythrinus erythrinus (Erythrinidae) mimicking a female of the rivulid Rivulus agilae (Brosset, 1997). The rarity of freshwater records for this type of interaction may be due to environmental conditions or scientific focus. Since this environment generally has limited underwater visibility, it is less likely that behavioural interactions that strongly depend on vision will evolve (see example regarding cleaning behaviour in Carvalho et al., 2003a).

Maybe some ecological interactions known for marine environment have never evolved in the freshwater (Carvalho et al., 2003b). On the other hand, it is possible that further observational studies in freshwater environments will uncover a rich diversity of ecological interactions among diverse fauna, as previously pointed for other complex interactions between Neotropical freshwater fishes (Carvalho et al., 2003b).

Bom Jardim District, in Nobres Municipality, northern Mato Grosso State, Brazil, holds part of the headwater streams that flow to the Paraguay River basin. These streams run over karstic terrain, with clear waters that facilitate underwater observations. They support a rich fish fauna, including the dourado Salminus brasiliensis (Characidae: Salmininae) (Reis et al., 2003), a large piscivorous apex predator (Britski et al., 2007). This fish start acting as a piscivore early, just after its post-larval stage (Rossi, 1989). As a stalking piscivore, the dourado rushes rapidly against its prey, taking advantage of its high swimming speed. In clear waters, although, the surprise factor is reduced since visually oriented preys can better perceive the foraging stalker presence and so behave to avoid its approach.

In the streams inhabited by juvenile dourados there are also large schools of piraputangas Brycon hilarii (Characidae), curimbas Prochilodus lineatus (Prochilodontidae) and piaustrês-pintas Leporinus friderici (Anostomidae), whose adults seem to be too large to serve as prey of the dourados. Other fishes, such as tetras (Astyanax spp., Moenkhausia spp.; Characidae) of about 3-6 cm total length (TL) also occur in these areas and are potential prey items for juvenile dourado (Almeida et al., 1997). Piraputangas may also be preyed on by adult dourados (Sabino \& Carvalho, 2008). Young dourados were frequently observed swimming amidst schools of piraputangas in the clear waters of headwater streams of Bom Jardim region. Juvenile dourados' body colour pattern are similar to piraputangas', mainly the dark steak in the caudal fin that goes from the middle of the caudal peduncle to the tip of the median rays (see Britski et al., 2007). Here we describe an alternative predation tactic by juvenile dourados $S$. brasiliensis in headwater streams of the Paraguay River basin.

Underwater observations were conducted in the Salobras (five sessions) and Estivado (seven sessions) streams in Bom Jardim District, Nobres Municipality, Mato Grosso State ( $14^{\circ}$ 32'55.7'S $\left.55^{\circ} 52^{\prime} 13.7^{\prime \prime} \mathrm{W}\right)$. The study sites have sandy substrate and horizontal water transparency greater than $5 \mathrm{~m}$. The social and foraging behaviour of the dourados were observed in the field during snorkelling sessions using free sampling and focal animal approaches (Lehner, 1996), over the course of 11 sessions and a total of $43 \mathrm{~h}$ of observations conducted between June and December 2009. Additional $11 \mathrm{~h}$ of further observations were made between January 2007 and July 2008 at Bodoquena Plateau Rivers, Mato Grosso do Sul State. During these sessions we quantified the number of dourados and piraputangas in the mixed species schools. The number of rushes against a prey by the dourados was measured in 12 sessions of 15 min of continuous observation each. These observation records involved at least five different individuals and comprised six records of dourados foraging among the piraputangas and six foraging apart from them. We recorded these behavioural interactions by photos and videos using a digital $7 \mathrm{Mp}$ camera. We estimated the total length of the fishes by comparing animal size with objects photographed at similar distances. A Student's T-test was used to compare the mean number of rushes of dourados foraging alone or among piraputangas $(\alpha<0.05)$.

Dourados of up to $30 \mathrm{~cm}$ TL were found foraging among similar-sized piraputangas. Juvenile dourados are less yellowish than adult conspecifics and exhibit more reddish fins (Fig. 1a-b). These piscivores stayed in the centre of the piraputanga's school (Fig. 1c) and moved to the border of the school only to attack tetras. After the attack the dourado left the piraputangas school ( $8.9 \%$ of 335 rushes) or returned to it (91.1\%). By the end of the afternoon, between 16:00 and 17:30 h, the dourados left the piraputangas and stayed stationary close to the bottom of the streams. Larger adults foraged apart from the piraputanga schools, which actively avoided them. In fact, we recorded adult dourados preying on piraputangas corresponding to 0.7 times the dourado's total length. That occurred while the piraputangas were foraging in groups of five to 40 individuals, as observed in five occasions at Bodoquena Plateau streams (Fig. 1d).

The ratio of piraputangas:dourados in the mixed schools were 4-12:1 (mean $\pm \mathrm{SD}=7.8 \pm 3.03$ ). The dourados not only stayed longer among the piraputangas $(78 \%$ of the time against $22 \%$ foraging alone, $n=43 \mathrm{~h}$ ) but also rushed more often against their prey when they were among the piraputangas ( 53 rushes $/ \mathrm{h} v s .14$ rushes $/ \mathrm{h} ; \mathrm{t}=1.48 ; \mathrm{p}<0.001$; $\mathrm{n}=10$ ), always using the stalking tactic (sensu Keenleyside, 1979). No prey capture was clearly observed, thus it was not possible to determine if the mimicry enhanced the predatory success of juvenile dourados.

The example of aggressive mimicry reported in the present 


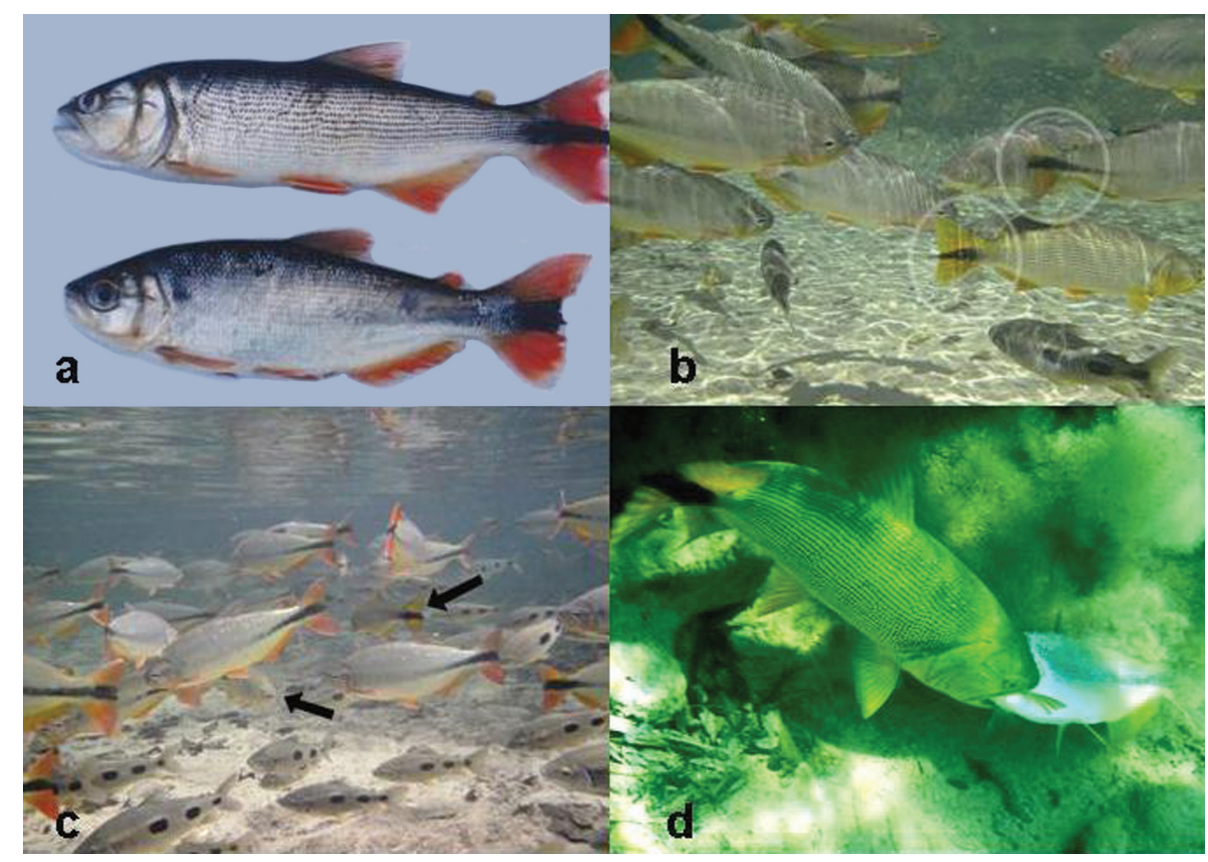

Fig. 1. Aggressive mimicry between the dourados Salminus brasiliensis and the piraputanga Brycon hilarii. Notice the resemblance in fins, general body colours and shape between the dourado (top) and the piraputanga (bottom) (a). Mixed school of about $30 \mathrm{~cm}$ total length piraputangas and dourados; the white circles point the similarity in caudal fin's colour in live individuals of both species (b). Juvenile dourados (black arrows) mimicking the piraputangas in a mixed school, both fishes were about $30 \mathrm{~cm} \mathrm{TL}$ (c). Adult dourado preying a piraputanga; mimicry is expected to end when dourados are 0.3 times bigger than the piraputangas that they eat (d). Photos: JS (a and d), LNC (b and c).

study fits the first trend of this relationship described by Sazima (2002), in which fish species that feed on smaller preys tend to join and mimic fish species which do not represent a threat to its probable prey. In this way, the more abundant frugivorous piraputangas from Bom Jardim and Bodoquena streams, which are no menace to the tetras (Reys et al., 2009), probably serve as a source of camouflage for the juvenile dourado and allow the occurrence of aggressive mimicry. One of the requirements for the efficiency of the aggressive mimicry is that the number of mimics must be smaller than the number of models because this reduces the probability of the prey recognizing the risks offered by the mimics (Sazima, 2002), and our findings fit this prediction.

Our results regarding the predatory tactics of the piscivorous $S$. brasiliensis increase the list of freshwater aggressive mimics presented by Sazima (2002). We believe that the aggressive mimicry shown by juvenile dourados may have evolved under the selective pressure generated by the clear waters of the studied streams, which may reduce the predation success of alternative predatory tactics employed in turbid water environments. We also believe that streams similar to those from Bom Jardim and Bodoquena, which hold both $S$. brasiliensis and B. hilarii are potential candidates to the occurrence of this opportunistic interaction. In this context, clear waters of lowland Pantanal region are also predicted to hold new occurrences of aggressive mimicry involving visually oriented piscivorous fishes.

\section{Acknowledgements}

The present work was funded by Fundação de Amparo à Pesquisa do Mato Grosso, FAPEMAT (Process 002.191/2007), which also offered a scholarship to PT. We also thank the Fundação de Apoio ao Desenvolvimento do Ensino, Ciência e Tecnologia do Estado de Mato Grosso do Sul, FUNDECT, for essential financial support. We would like to thank Mrs. Joana Lambert, Mr. Kleber Oliveira, Antônio Campos and Isaías de Almeida for the access to the study sites. We also thank João Paulo Krajewski and two anonymous referees for the critical review of this manuscript. JS is recipient of scholarships from the CNPq-Brazil.

\section{Literature Cited}

Almeida, V. L. L., N. S. Hahn \& A. E. A. M. Vazzoler. 1997. Feeding patterns in five predatory fishes of the high Parana River floodplain (PR, Brazil). Ecology of Freshwater Fish, 6: 123-133.

Auster, P. J. 2008. Variation in search and predatory attack strategies of shark mackerel Grammatorcynus bicarinatus. Journal of the Marine Biological Association of the United Kingdom, 88: 847849.

Britski, H. A., K. Z. S. Silimon \& B. S. Lopes. 2007. Peixes do Pantanal. 2a Edição. Brasília, EMBRAPA, 230p.

Brosset, A. 1997. Aggressive mimicry by the characid fish Erythrinus erythrinus. Ethology, 103: 926-934. 
Carvalho, L. N., K. Del-Claro \& M. R. Takemoto. 2003a. Hostparasite interaction between Branchiurans (Crustacea: Argulidae) and piranhas (Osteichthyes: Serrasalminae) in the Pantanal wetland of Brazil. Environmental Biology of Fishes, 67: 289296.

Carvalho, L. N., R. Arruda \& J. Zuanon. 2003b. Record of cleaning behavior by Platydoras costatus (Siluriformes: Doradidae) in the Amazon Basin, Brazil. Neotropical Ichthyology, 1: 137-139.

Eibl-Eibesfeldt, I. 1955. Uber symbiosen, parasitismus und andere zwischenartliche beziehungen bei tropischen meeresfichen. Zeitschrift für Tierpsychologie, 12: 203-219.

Hobson, E.S. 1974. Feeding relationships of teleostean fishes on coral reefs in Kona, Hawaii. Fishery Bulletin, 72: 915-1031.

Keenleyside, M. H. A. 1979. Diversity and adaptation in fish behaviour. Berlim, Springer Verlag, 208p.

Lehner, P. N. 1996. Handbook of ethological methods. 2nd ed. Cambridge, Cambridge University Press, 672p.

Nico, L. G. \& D. C. Taphorn. 1988. Food habits of piranhas in the low llanos of Venezuela. Biotropica, 20: 311-321.

Randall, J. E. 2005. A review of mimicry in marine fishes. Zoological Studies, 44: 299-328.

Randall, J. E. \& H. A. Randall. 1960. Examples of mimicry and protective resemblance in tropical marine fishes. Bulletin of Marine Science, 1: 444-480.

Reis, R. E., S. O. Kullander \& C. J. Ferraris, Jr. 2003. Check list of the freshwater fishes of South and Central America. Porto Alegre, Edipucrs, 729p.
Reys, P., J. Sabino \& M. Galetti. 2009. Frugivory by the fish Brycon hilarii (Characidae) in Western Brazil. Acta Oecologica, 35(2): 136-141.

Rossi, L. M. 1989. Alimentación de larvas de Salminus maxillosus (Val. 1840) (Pisces, Characidae). Iheringia, Série Zoologia, 69: 49-59.

Sabino, J. \& L. N. Carvalho. 2008. Puxando mais brasa para nossa sardinha: estudar comportamento de peixes é muito produtivo e divertido. Pp. 145-165. In: Del-Claro, K., F. Prezoto \& J. Sabino. (Org.). As Distintas Faces do Comportamento Animal. 2a ed. Campo Grande, Editora UNIDERP, 422p.

Sazima, I. 1977. Possible case of aggressive mimicry in a neotropical scale-eating fish. Nature, 270: 510-512.

Sazima, I. 2002. Juvenile snooks (Centropomidae) as mimics of mojarras (Gerreidae), with a review of aggressive mimicry in fishes. Environmental Biology of Fishes, 65: 37-45.

Sazima, I. \& F. A. Machado. 1990. Underwater observations of piranhas in western Brazil. Environmental Biology of Fishes, 28: $17-31$.

Sazima, I., J. P. Krajewski, R. M. Bonaldo \& C. Sazima. 2005b. Wolf in a sheep's clothes: juvenile coney (Cephalopholis fulva) as an aggressive mimic of the brown chromis (Chromis multilineata). Neotropical Ichthyology, 3: 315-318.

Wickler, W. 1968. Mimicry in plants and animals. New York, McGraw-Hill, 255p.

Accepted February 20, 2011

Published June 30, 2011 